\title{
SISTEM DETEKSI WAJAH UNTUK IDENTIFIKASI KEHADIRAN MAHASISWA DENGAN MENGGUNAKAN METODE EIGENFACE PCA
}

\author{
Husni Sulaiman¹, Zahir Zainuddin², Supriadi Sahibu ${ }^{3}$ \\ ${ }^{1}$ Sistem Informasi \\ STMIK Bina Adinata \\ husninevergiveup@gmail.com \\ ${ }^{2}$ Teknik Informatika \\ Universitas Hasanuddin Makassar \\ zainuddinzahir@gmail.com \\ ${ }^{3}$ Pascasarjana Sistem Komputer \\ STMIK Handayani Makassar \\ supriadi.dit@gmail.com
}

\begin{abstract}
Abstrak
Pengenalan wajah merupakan salah satu cara pengenalan untuk keperluan identifikasi seseorang selain pengenalan sidik jari, suara, tanda tangan, retina mata dan sebagainya. Teknik identifikasi kehadiran Mahasiswa di STMIK Bina Adinata masih bersifat konvensional, yaitu setiap mahasiswa hanya mengisi atau menandatangani absensi pada saat mengikuti perkuliahan, hal ini tentunya kurang efektif karena biasanya ada mahasiswa yang tidak mengikuti perkuliahan tapi tetap tercatat hadir di absen dikarenakan adanya seorang mahasiswa yang menandatangani absensi mahasiwa yang tidak sempat hadir pada saat perkuliahan, atau yang lebih sering disebut Titip Absen. Tujuan dari penelitian ini adalah untuk membangun sebuah Sistem Deteksi Wajah Untuk Identifikasi Kehadiran Mahasiswa Dengan Menggunakan Metode Eigenface PCA dan Open CV Library. Penelitian ini dilaksanakan di kampus STMIK Bina Adinata. Sistem ini dapat bekerja secara Realtime dengan menggunakan metode Eigenface PCA (Priciple Component Analysis). Hasil Penelitian yang diperoleh menunjukkan bahwa sistem dapat bekerja secara Realtime atau secara langsung, jadi sistem dapat mendeteksi wajah mahasiswa yang sedang mengikuti perkuliahan Sistem ini dapat mengenali citra wajah baik dalam posisi lurus maupun menyamping. Sistem dapat mendeteksi bukan Cuma 1 wajah saja, tetapi sistem dapat mendeteksi semua wajah yang tertangkap kamera. Tingkat Keberhasilan Akurasi sangat dipengaruhi oleh Pencahayaan, semakin terang Pencahayaan maka tingkat keberhasilan akurasi juga semakin tingggi. Total Akurasi keseluruhan dari Segi Pencahayaan adalah 90 \% dan Total Akurasi keseluruhan dari segi Posisi Wajah adalah 86,6 \%
\end{abstract}

Kata Kunci : Deteksi Wajah, Metode Eigenface PCA, Open CV.

\begin{abstract}
Identifying Face recognition is one of the introductory approaches for the purpose of someone besides other biometric approaches such as fingerprint recognition, voice, signature, identifying eyes and so on. Face recognition system which is included with the field of image processing can be combined with the attendance system so that it becomes one of the interesting things to do, the attendance system it can be applied with the way of identification face. Purpose of this research is to build a Face Detection System to Identify Student Attendance with Eigenface PCA Method and Open CV Library. This research was carried out at the STMIK Bina Adinata its a one of University, This system work in realtime using the Eigenface PCA (Primary Component Analysis) method. The research results obtained indicate that the system work in realtime or directly, so the system detect the faces of students who are attending lectures. This system can recognize facial images both in a straight and sideways position. The system can detect not only one face, but the system can detect all faces caught on camera. The Success rate Accuracy very influenced by the lighting, the lighting that more brighter will make success of accuracy increasingly high.
\end{abstract}

Keywords: Face Detection, Method of Eigenface PCA, Open CV. 


\section{PENDAHULUAN}

Secara garis besar metode yang digunakan dalam proses pengenalan wajah ada 3 macam, yaitu metode Holistik, metode berdasarkan ciri dan metode Hybrid. Pendeteksian wajah merupakan tahap awal yang penting dalam sistem pengenalanan wajah otomatis. Dalam suatu citra tunggal, tujuan dari pendeteksian wajah adalah mengidentifikasi semua area yang ada dalam citra untuk menemukan area wajah dan area bukan wajah. (Yang, Kriegman, \& Ahuja, 2002)

Dalam pendeteksian citra, warna memiliki kepekaan yang tinggi terhadap perubahan cahaya, maka untuk mengatasinya dilakukan transformasi citra RGB ke dalam sebuah ruang warna yang komponen luminasi dan kromatiknya dipisahkan sehingga cukup digunakan kromatik saja untuk proses deteksi warna kulit (Chang \& Robles, 2000). Salah satu contoh pendeteksian citra yang bisa diterapkan adalah identifikasi kehadiran atau absesnsi berdasarkan wajah yang bisa digunakan untuk mengidentifikasi kehadiran mahasiswa (Yusuf, Ginardi, \& Ahmadiyah, 2016).

Teknik identifikasi kehadiran Mahasiswa di STMIK Bina Adinata masih bersifat konvensional (Purnia \& Sumitro, 2015), yaitu setiap mahasiswa hanya mengisi atau menandatangani absensi pada saat mengikuti perkuliahan, hal ini tentunya kurang efektif (Suhery \& Ruslianto, 2017) karena biasanya ada mahasiswa yang tidak mengikuti perkuliahan tapi tetap tercatat hadir di absen dikarenakan adanya seorang mahasiswa yang menandatangani absensi mahasiwa yang tidak sempat hadir pada saat perkuliahan, atau yang lebih sering disebut Titip Absen (Hertyana, 2016).

Berdasarkan permasalahan tesebut maka diperlukan sebuah Sistem Deteksi Wajah Untuk Identifikasi Kehadiran Mahasiswa, dengan adanya aplikasi detekasi wajah ini diharapkan dapat memberikan informasi yang lebih akurat tentang kehadiran Mahasiswa pada saat mengikuti perkuliahan.

Wajah merupakan bagian dari tubuh manusia yang menjadi fokus perhatian di dalam interaksi sosial, wajah memainkan peranan vital dengan menunjukan identitas dan emosi. Kemampuan manusia untuk mengetahui seseorang dari wajahnya sangat luar biasa. Kita dapat mengenali ribuan wajah karena frekuensi interaksi yang sangat sering ataupun hanya sekilas bahkan dalam rentang waktu yang sangat lama. Bahkan kita mampu mengenali seseorang walaupun terjadi perubahan pada orang tersebut karena bertambahnya usia atau pemakaian kacamata atau perubahan gaya rambut.
Oleh karena itu wajah digunakan sebagai organ dari tubuh manusia yang dijadikan indikasi pengenalan seseorang atau face recognition. Face recognition atau pengenalan wajah merupakan salah satu teknologi biometrik yang banyak diaplikasikan khususnya dalam sistem security. Sistem absensi dengan wajah, mengenali pelaku tindak kriminal dengan CCTV adalah beberapa aplikasi dari pengenalan wajah, efisiensi dan akurasi menjadi faktor utama mengapa pengenalan wajah banyak diaplikasikan khususnya dalam sistem security

Tahapan Pengenalan Wajah :

1) Pengenalan wajah (face recognition) yaitu membandingkan citra wajah masukan dengan suatu database wajah dan menemukan wajah yang paling cocok dengan citra masukan tersebut.

2) Autentikasi wajah (face authentication) yaitu menguji keaslian/kesamaan suatu wajah dengan data wajah yang telah diinputkan sebelumnya.

3) Lokalisasi wajah (face localization) yaitu pendeteksian wajah namun asumsi hanya ada satu wajah di dalam citra

4) Penjejakan wajah (face tracking) yaitu memperkirakan lokasi suatu wajah di dalam video secara real time.

5) Pengenalan ekspresi wajah (facial expression recognition) untuk mengenali kondisi emosi manusia

\section{METODE PENELITIAN}

\section{Rancangan Sistem}

Berikut ini adalah gambaran tentang perancangan Sistem Deteksi Wajah Untuk Identifikasi Kehadiran Mahasiswa Dengan Menggunakan Metode Eigenface PCA di STMIK Bina Adinata secara keseluruhan.

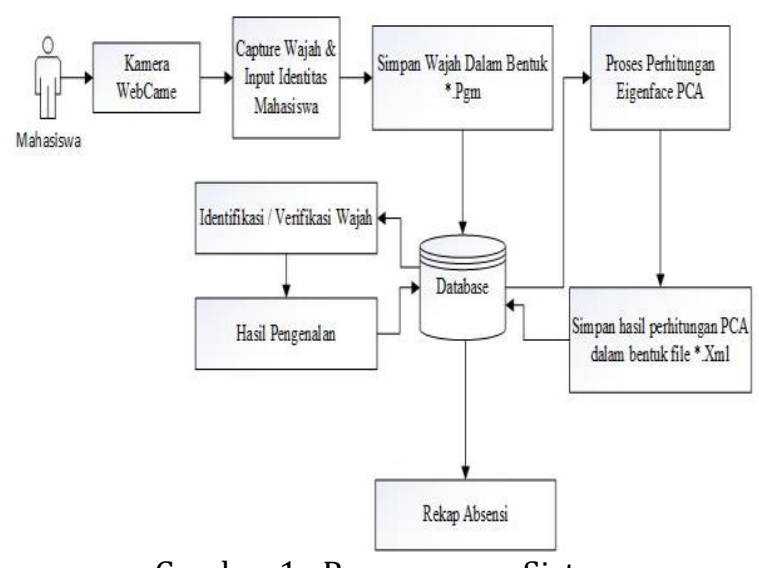

Gambar 1 : Perancangan Sistem 


\section{Cara Kerja Sistem :}

Tahap pertama yang harus dilakukan adalah, menginput Biodata mahasiswa dan mengcapture wajah mahasiswa sebagai data latih dimana nantinya data ini akan di olah dan di cocokkan dengan data uji, data latih ini kemudian akan disimpan kedalam Database. Selanjutnya sistem akan melakukan proses perhitungan Eigenface PCA, Setelah proses perhitungan selesai, selanjutnya sistem akan menyimpan hasil perhitungan tersebut kedalam bentuk file ${ }^{*} \mathrm{xml}$. Berdasarkan dari hasil perhitungan tersebut selanjutnya sistem akan mengidentivikasi atau memverifikasi wajah dari data latih dengan data uji, setelah di verifikasi sistem akan menampilkan hasil pengenalan wajah tersebut, kemudian menyimpannya lagi kedalam Database.

\section{Penyimpanan Data}

Dalam sistem ini penyimpanan data dapat disimpan dalam database dan juga dataset. Database pada program ini menggunakan SQLiteStudio. Adapun Rancangan Database nya dapat dilihat pada tabel dibawah ini.

Tabel 1 : Rancangan Database

\begin{tabular}{lc}
\hline \multicolumn{1}{c}{ Name } & Date Type \\
\hline Mahasiswa Id & Integer \\
\hline Nama Lengkap & Text \\
\hline Nim & Text \\
\hline Jenis Kelamin & Text \\
\hline Kelas & Text \\
\hline Absen & Text \\
\hline Tanggal & Varchart \\
\hline Jam & Time \\
\hline
\end{tabular}

Sedangkan untuk menyimpan citra wajah tiap mahasiswa penulis menggunakan data set. Untuk menghubungkan citra wajah dengan database sistem harus di generate terlebih dahulu agar data yang ada di database dapat disesuaikan atau di cocokkan dengan data di dataset.

\section{Jenis Penelitian}

Untuk menyempurnakan data - data yang dibutuhkan dalam penyusunan Penelitian ini, maka penulis akan melakukan pengumpulan data dengan menggunakan 2 cara yaitu :

1) Penelitian Kepustakaan (Library Research), yaitu pengumpulan data dengan cara membaca buku melalui literature, tutorial - tutorial maupun artikel dari internet yang bersifat ilmiah yang ada hipotesisnya dengan materi pembahasan.

2) Penelitian Lapangan (Field Research),yaitu dilakukan dengan cara mengumpulkan data secara langsung kepada objek penelitian yaitu pada STMIK Bina Adinata.

\section{Waktu dan Tempat Penelitian}

Penelitian ini akan dilaksanakan selama 5 bulan, Mulai Februari sampai Juni 2018 di STMIK Bina Adinata.

\section{Target/Subjek Penelitian}

Target Penelitian ini adalah Mahasiswa STMIK Bina Adinata

\section{Prosedur \\ Renacana Kegiatan}

1. Pengumpulan Data

Pada Tahap ini merupakan tahap dimana penulis mengumpulkan data megenai obyek yang akan diteliti dengan cara melakukan Observaasi langsung ke lapangan.

2. Analisis dan desain Sistem

Pada tahap ini peneliti akan melakukan perancangan sistem yang akan dibuat pada penelitian ini.

3. Pembuatan Aplikasi

Pada tahap ini peneliti akan mulai melakukan pembuatan aplikasi Sistem deteksi wajah.

4. Pengujian

Pada tahap ini peneliti akan mulai melakukan pengujian terhadap aplikasi yang telah dibuat.

5. Implementasi

Tahap ini merupakan tahap penerapan aplikasi yang telah dibuat oleh peneliti.

Data, Intrumen, dan Teknik Pengumpulan Data

Adapun teknik pengumpulan data yang dilakukan oleh penulis yaitu dengan cara Observasi, yaitu mengamati secara langsung pada saat proses perkuliahan berlangsung, dan meperhatikan pola perilaku dari mahasiswa pada saat perkuliahan.

\section{HASIL PENELITIAN DAN PEMBAHASAN}

\section{Implementasi Sistem}

Aplikasi ini dibuat dengan bahasa pemrograman Python dan dikombinasikan dengan menggunakan OpenCV Library. Sistem yang dibuat ini merupakan sistem yang berbasis Desktop, dimana proses - proses dalam menjalankan sistem dibuat secara Realtime dan mudah dipahami dalam penggunaannya.

\section{Tahapan - Tahapan Algoritma Eigenface}

Perhitungan Eigenface untuk gambar Training

1) Penyusunan Flatvector matriks citra 
Dari data training image ( $\Gamma$ )yang tersediah langkah selanjutnya adalah menyusun seluruh data training menjadi satu matriks tunggal. Representasikan semua matriks training menjadi matriks linier $\mathrm{Nx} 1$ atau flatvector seperti gambar 3 , 4 dan 5.
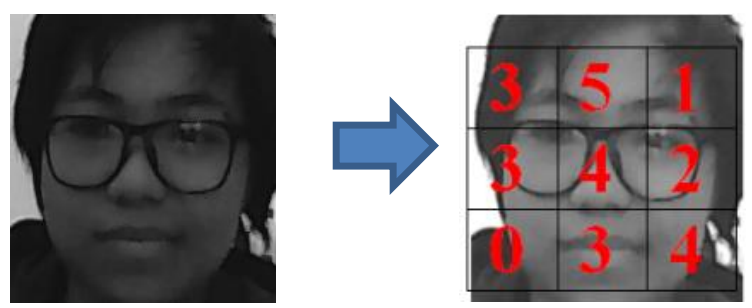

Gambar 2 : Training 1

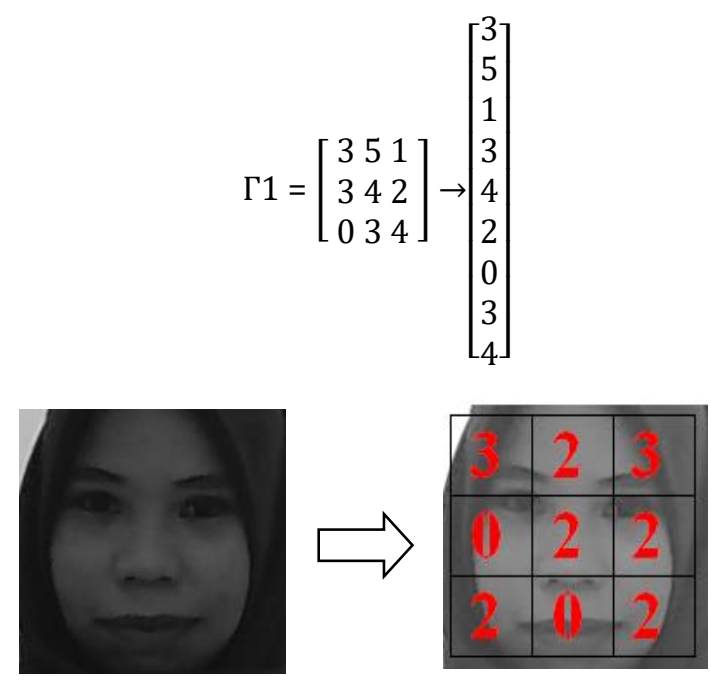

Gambar 3 : Training 2

$$
\Gamma 2=\left[\begin{array}{lll}
3 & 2 & 3 \\
0 & 2 & 2 \\
2 & 0 & 2
\end{array}\right] \rightarrow\left[\begin{array}{l}
3 \\
2 \\
3 \\
0 \\
2 \\
2 \\
2 \\
0 \\
2
\end{array}\right]
$$

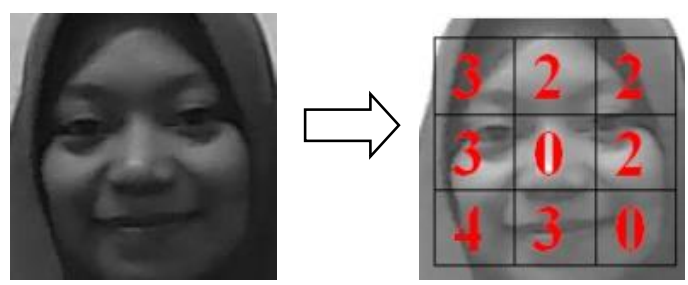

Gambar 4 : Training 3

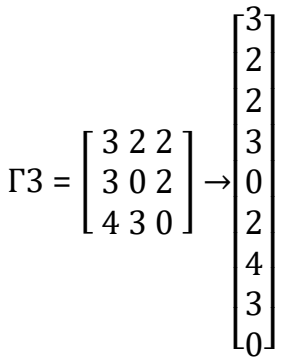

Menghitung nilai tengah atau mean $(\Psi)$

$$
\Psi=\frac{1}{3} \sum_{n=1}^{3} \Gamma n
$$

$$
\Psi=\frac{1}{3}\left(\left[\begin{array}{l}
3 \\
5 \\
1 \\
3 \\
4 \\
2 \\
0 \\
3 \\
4
\end{array}\right]+\left[\begin{array}{l}
3 \\
2 \\
3 \\
0 \\
2 \\
2 \\
0 \\
0 \\
2
\end{array}\right]+\left[\begin{array}{l}
3 \\
2 \\
2 \\
3 \\
0 \\
2 \\
4 \\
3 \\
0
\end{array}\right]\right)=\left[\begin{array}{l}
3 \\
3 \\
2 \\
2 \\
2 \\
2 \\
2 \\
2 \\
2
\end{array}\right]
$$

Menghitung nilai selisih antara training image $(\Gamma)$ dengan nilai mean $(\Psi)$

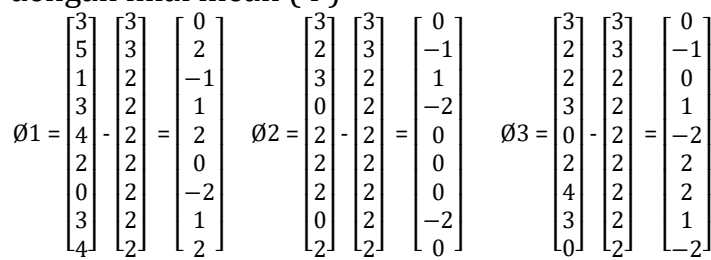

Menghitung nilai matriks kovarian

$$
\begin{gathered}
\mathrm{L}=\left[\begin{array}{ccccccccr}
0 & 2 & -1 & 1 & 2 & 0 & -2 & 1 & 2 \\
0 & -1 & 1 & -2 & 0 & 0 & 0 & -2 & 0 \\
0 & -1 & 0 & 1 & -2 & 2 & 2 & 1 & -2
\end{array}\right]\left[\begin{array}{llr}
0 & 0 & 0 \\
2 & -1 & -1 \\
-1 & 1 & 0 \\
1 & -2 & 1 \\
2 & 0 & -2 \\
0 & 0 & 2 \\
-2 & 0 & 2 \\
1 & -2 & 1 \\
2 & 0 & -2
\end{array}\right] \\
L \\
\mathrm{~L}\left[\begin{array}{cccc}
19 & -7 & -12 \\
-7 & 10 & -3 \\
-12 & -3 & 19
\end{array}\right]
\end{gathered}
$$

Hitung nilai Eigen value $(\lambda)$ dan eigen vector $(v)$ dari matriks kovarian

$$
\begin{aligned}
& 0=\left|\lambda\left[\begin{array}{lll}
1 & 0 & 0 \\
0 & 1 & 0 \\
0 & 0 & 1
\end{array}\right]-\left[\begin{array}{ccc}
19 & -7 & -12 \\
-7 & 10 & -3 \\
-12 & -3 & 19
\end{array}\right]\right| \\
& 0=\left|\left[\begin{array}{ccc}
\lambda-19 & 7 & 12 \\
7 & \lambda-10 & 3 \\
12 & 3 & \lambda-19
\end{array}\right]\right|
\end{aligned}
$$

Nilai Eigen Vector diperoleh dengan cara mensubtitusi eigen value kedalam persamaan $(\lambda I-L) \cup=0$. Eigen vector masing - masing eigen 
value didapat berdasarkan masing - masing kolom eigen value dan kemudian dihimpun kembali menjadi satu matriks.

Untuk $\lambda 1=1.1641$

$\left[\begin{array}{ccc}\lambda-19 & 7 & 12 \\ 7 & \lambda-10 & 3 \\ 12 & 3 & \lambda-19\end{array}\right]\left[\begin{array}{l}u 1 \\ v 2 \\ v 3\end{array}\right]=\left[\begin{array}{l}0 \\ 0 \\ 0\end{array}\right] \Longrightarrow v 1=\left[\begin{array}{l}-0.5870 \\ -0.6354 \\ -0.5018\end{array}\right]$ Untuk $\lambda 2=15.4227$

$\left[\begin{array}{ccc}\lambda-19 & 7 & 12 \\ 7 & \lambda-10 & 3 \\ 12 & 3 & \lambda-19\end{array}\right]\left[\begin{array}{l}v 1 \\ v 2 \\ v 3\end{array}\right]=\left[\begin{array}{l}0 \\ 0 \\ 0\end{array}\right] \Longrightarrow v 2=\left[\begin{array}{c}0.3529 \\ -0.7586 \\ 0.5477\end{array}\right]$ Untuk $\lambda 3=31.4131$

$\left[\begin{array}{ccc}\lambda-19 & 7 & 12 \\ 7 & \lambda-10 & 3 \\ 12 & 3 & \lambda-19\end{array}\right]\left[\begin{array}{l}v 1 \\ v 2 \\ v 3\end{array}\right]=\left[\begin{array}{l}0 \\ 0 \\ 0\end{array}\right] \Longrightarrow v 3=\left[\begin{array}{c}-0.7286 \\ 0.1444 \\ 0.6695\end{array}\right]$

Maka C $=\left[\begin{array}{ccc}-0.5870 & 0.3529 & -0.7286 \\ -0.6354 & -0.7586 & 0.1444 \\ -0.5018 & 0.5477 & 0.6695\end{array}\right]$

Menghitung nilai Eigenface $(\mu)$

$\mu 1=\mathrm{v} \times \varnothing 1$

$\mu 1=\left[\begin{array}{ccc}-0.5870 & 0.3529 & -0.7286 \\ -0.6354 & -0.7586 & 0.1444 \\ -0.5018 & 0.5477 & 0.6695\end{array}\right] \times\left[\begin{array}{lrr}0 & 2 & -1 \\ 1 & 2 & 0 \\ -2 & 1 & 2\end{array}\right]$

$\mu 1=\left[\begin{array}{ccc}1.8102 & -1.1967 & -0.8703 \\ -1.0474 & -2.6435 & 0.9242 \\ -0.7913 & 0.7614 & 1.8404\end{array}\right]$

$\mu 2=\left[\begin{array}{ccc}-0.5870 & 0.3529 & -0.7286 \\ -0.6354 & -0.7586 & 0.1444 \\ -0.5018 & 0.5477 & 0.6695\end{array}\right] \times\left[\begin{array}{ccc}0 & -1 & 1 \\ -2 & 0 & 0 \\ 0 & -2 & 0\end{array}\right]$

$\mu 2=\left[\begin{array}{lll}-0.7058 & 2.0442 & -0.5870 \\ 1.5172 & 0.3466 & -0.6354 \\ -1.0954 & -0.8372 & -0.5018\end{array}\right]$

$\mu 3=\left[\begin{array}{ccc}-0.5870 & 0.3529 & -0.7286 \\ -0.6354 & -0.7586 & 0.1444 \\ -0.5018 & 0.5477 & 0.6695\end{array}\right] \times\left[\begin{array}{ccc}0 & -1 & 0 \\ 1 & -2 & 2 \\ 2 & 1 & -2\end{array}\right]$

$\mu 3=\left[\begin{array}{lcr}-1.1044 & -0.8475 & 0.6695 \\ -0.4698 & 2.2969 & -1.8060 \\ 1.8867 & 0.0758 & -0.2436\end{array}\right]$

2) Proses Pengenalan Wajah

Proses pengenalan wajah dilakukan dengan cara mengenali gambar tes, kemudian mencocokkan dengan training image yang telah telah tersimpan. Tahap pertama dimulai dari mengubah matriks persegi menjadi flatvector hingga memperoleh nilai eigenface $(\mu)$ seperti gambar dibawah ini
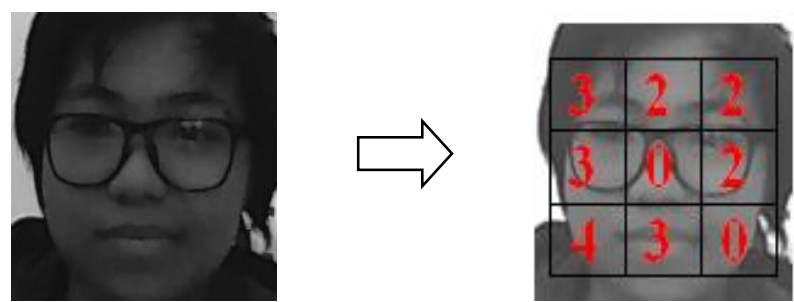

Gambar 5 : Gambar Test

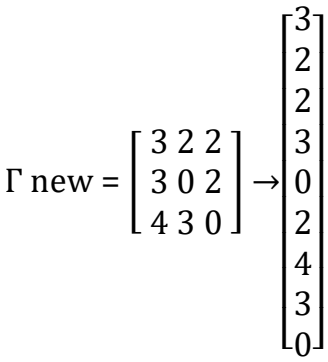

Setelah merepresentasikan gambar test ke flatvector, kemudian mencari selisi $(\varnothing)$ antara gambar test dengan nilai mean $(\Psi)$.

$$
\emptyset \text { new }=\left[\begin{array}{l}
3 \\
2 \\
2 \\
3 \\
0 \\
2 \\
4 \\
3 \\
0
\end{array}\right]-\left[\begin{array}{l}
3 \\
3 \\
2 \\
2 \\
2 \\
2 \\
2 \\
2 \\
2
\end{array}\right]=\left[\begin{array}{c}
0 \\
2 \\
-2 \\
1 \\
2 \\
0 \\
-2 \\
1 \\
3
\end{array}\right]
$$

Dari nilai selisih, maka nilai eigenface dapat dihitung.

$$
\begin{aligned}
\mu \text { new } & =\left[\begin{array}{ccc}
-0.5870 & 0.3529 & -0.7286 \\
-0.6354 & -0.7586 & 0.1444 \\
-0.5018 & 0.5477 & 0.6695
\end{array}\right] \times\left[\begin{array}{llr}
0 & 2 & -2 \\
1 & 2 & 0 \\
-2 & 1 & 3
\end{array}\right] \\
\mu \text { new } & =\left[\begin{array}{ccc}
1.8102 & -1.1967 & -1.0120 \\
-1.0474 & -2.6435 & 1.7039 \\
-0.7913 & 0.7614 & 3.0120
\end{array}\right]
\end{aligned}
$$

Setelah nilai eigenface untuk gambar test diperoleh maka kita bisa melakukan identifikasi dengan menentukan jarak terpendek (ecludian distance) dengan eigenface dari eigenvector training image.

$\left.\varepsilon 1=\mid \begin{array}{ccc}-0.5870 & 0.3529 & -0.7286 \\ -0.6354 & -0.7586 & 0.1444 \\ -0.5018 & 0.5477 & 0.6695\end{array}\right]\left[\begin{array}{ccc}-0.5870 & 0.3529 & -0.7286 \\ -0.6354 & -0.7586 & 0.1444 \\ -0.5018 & 0.5477 & 0.6695\end{array}\right] \|$
$\varepsilon 1=\sqrt{(0)^{2}+(0)^{2}+(-0.1417)^{2}+(0)^{2}+(0)^{2}+(0.7797)^{2}+(0)^{2}+(0)^{2}+}$
$\varepsilon 1=\sqrt{1.9997}=1.4141$ $\left.\varepsilon 2=|| \begin{array}{ccc}1.8102 & -1.1967 & -1.0120 \\ -1.047 & -2.6435 & 1.7039 \\ -0.791 & 0.7614 & 3.0120\end{array}\right]\left[\begin{array}{ccc}-0.7058 & 2.0442 & -0.5870 \\ 1.5172 & 0.3466 & -0.6354 \\ -1.09 & -0.8372 & -0.5018\end{array}\right] \mid$
$\varepsilon 2=\sqrt{\left(\begin{array}{c}(1.2197)^{2}+(10.5034)^{2}+(0.1806)^{2}+(6.5772)^{2}+(4.3685)^{2}+ \\ (5.4723)^{2}+(0.0924)^{2}+(2.5555)^{2}+(12.4171)^{2}\end{array}\right.}$
$\varepsilon 2=\sqrt{43.386}=6.5868$ $\varepsilon 3=||\left[\begin{array}{ccc}1.8102 & -1.1967 & -1.0120 \\ -1.047 & -2.6435 & 1.7039 \\ -0.791 & 0.7614 & 3.0120\end{array}\right]\left[\begin{array}{ccc}-1.1044 & -0.8475 & 2.1631 \\ -0.4698 & 2.2969 & -1.8060 \\ 1.8867 & 0.0758 & -0.2436\end{array}\right] \mid$
$\varepsilon 3 \quad \sqrt{(2.9146)^{2}+(0.3492)^{2}+(-3.1751)^{2}+(-0.5776)^{2}+(-4.9404)^{2}+}$
$\sqrt{(3.5099)^{2}+(-2.678)^{2}+(0.6856)^{2}+(3.2556)^{2}}$
$\varepsilon 3=\sqrt{73.999}=8.6022$

Dari hasil perhitungan nilai ecludian distance gambar training 1 , training 2 dan training 3 terhadap gambar test, maka nilai jarak eigenface 
yang terkecil di identifikasikan lebih mirip antara training 1 dengan gambar tes, dibandingakan dengan training 2 dan training 3.

\section{Pengujian Black Box}

Setelah aplikasi ini dibuat maka tahap selanjutnya adalah tahap uji coba dari tampilan aplikasi. Tahap uji coba ini dimulai dari memasukkan citra wajah sebagai data set, dimana data citra ini nantinya akan di cocokkan dengan data citra wajah yang dilakukan secara Real Time. Untuk lebih jelaskan perhatikan gambar dibawah ini :

Pengujian Menu Inputan Data Mahasiswa Tabel 2 : Pengujian Menu inputan data Mahasiswa

\begin{tabular}{lcl}
\multicolumn{3}{c}{ Mahasiswa } \\
\hline \multicolumn{1}{c}{ Test Factor } & Hasil & \multicolumn{2}{c}{ Keterangan } \\
\hline Menu inputan & & Dosen dapat melakukan \\
data Mahasiswa & $\sqrt{ }$ & $\begin{array}{l}\text { penginputan data Mahasiswa } \\
\text { yang mengikuti Mata Kuliah }\end{array}$ \\
\hline 7* Absensiface Recognition & & \multicolumn{2}{l}{$\times$}
\end{tabular}

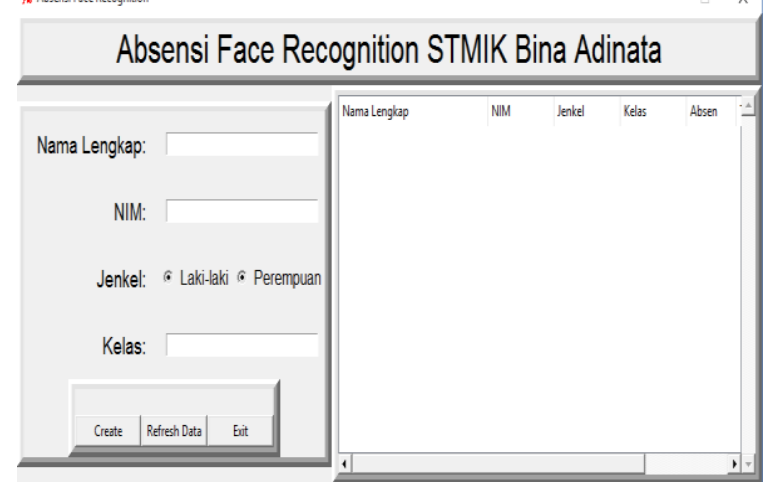

Pengujian Pengambilan Citra Wajah

Tabel 3 : Pengujian Pengambilan Citra Wajah

\begin{tabular}{lll}
\hline \multicolumn{1}{c}{ Test Factor } & Hasil & \multicolumn{1}{c}{ Keterangan } \\
\hline $\begin{array}{l}\text { Proses pengambilan } \\
\text { citra wajah }\end{array}$ & $\sqrt{ }$ & $\begin{array}{l}\text { Semua Mahasiswa yang } \\
\text { mengikuti perkuliahan }\end{array}$ \\
& harus di data terlebih \\
& dahulu, bukan Cuma data \\
& identitas tapi juga data \\
& mengenai citra wajah tiap \\
& mahasiswa.
\end{tabular}

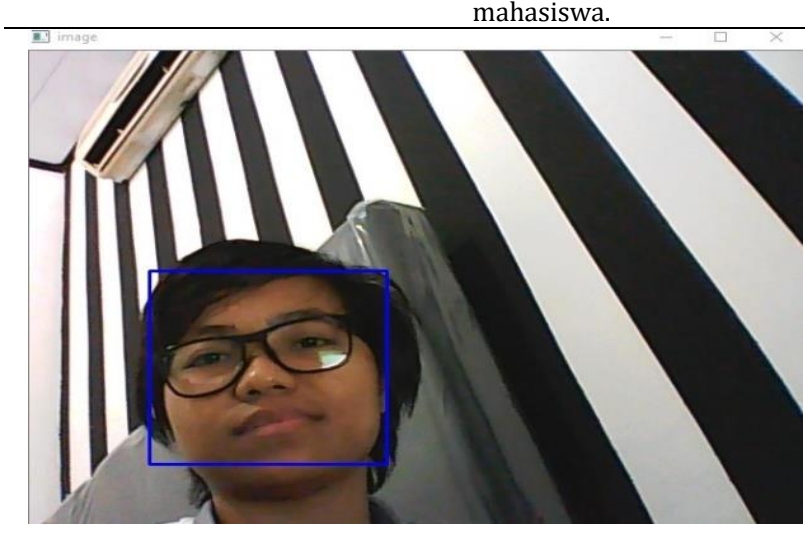

Tabel 4 : Pengujian Pendeteksian 1 Citra Wajah

\begin{tabular}{lll}
\hline \multicolumn{1}{c}{ Test Factor } & Hasil & \multicolumn{2}{c}{ Keterangan } \\
\hline Proses & & Pada Tampilan ini \\
Pendeteksian & $\sqrt{ }$ & sitem $\quad$ dapat \\
1 citra wajah & & $\begin{array}{l}\text { mengenali } 1 \text { citra } \\
\end{array}$ \\
& wajah secara Real \\
& Time dalam satu kali \\
& Pendeteksian. \\
\hline
\end{tabular}

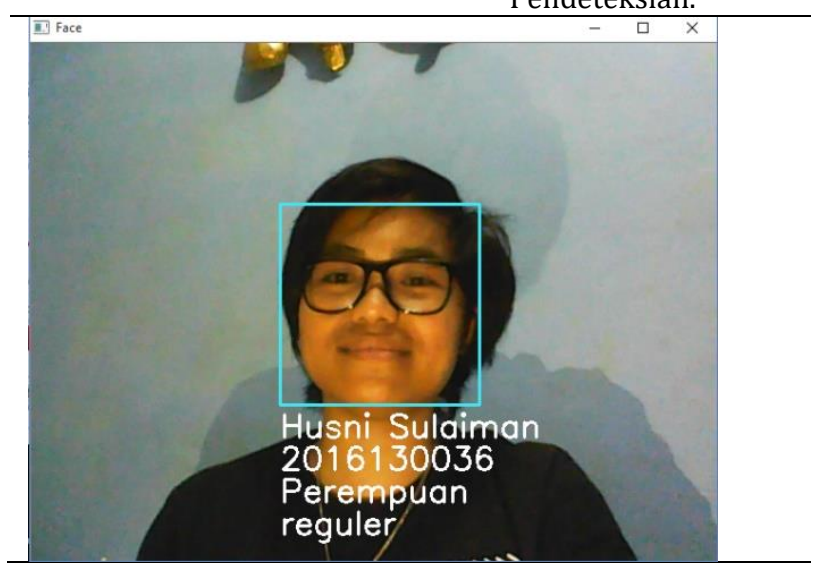

Pengujian Pendeteksian 2 Citra Wajah

Tabel 5 : Pengujian Pendeteksian 2 Citra Wajah

\begin{tabular}{llll}
\hline \multicolumn{1}{c}{ Test Factor } & Hasil & \multicolumn{2}{c}{ Keterangan } \\
\hline $\begin{array}{l}\text { Proses } \\
\text { Pendeteksian } \\
\text { citra wajah }\end{array}$ & 2 & $\sqrt{ }$ & $\begin{array}{l}\text { Pada Tampilan ini sitem dapat } \\
\text { mengenali } 2 \text { citra wajah } \\
\text { sekaligus secara Real Time } \\
\text { dalam satu kali Pendeteksian. }\end{array}$
\end{tabular}

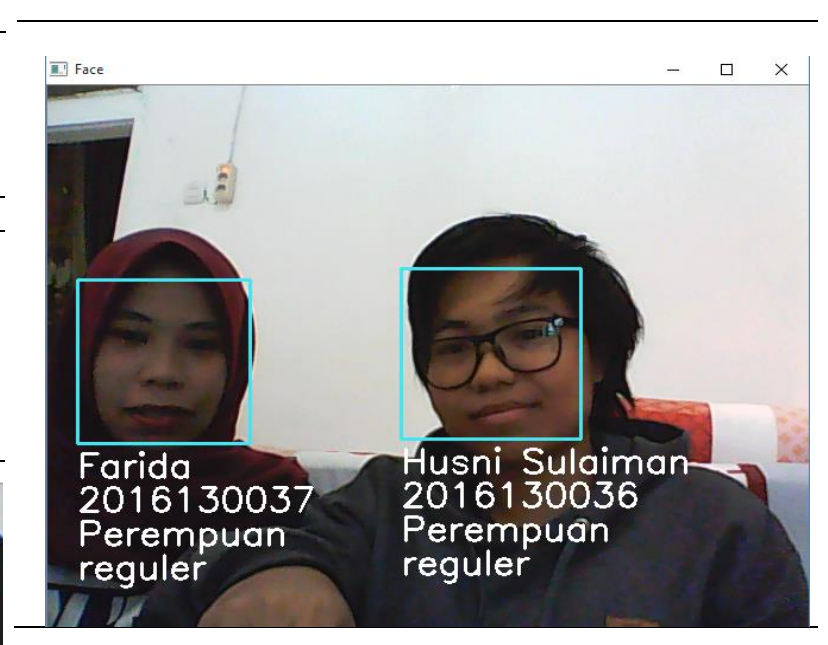

Pendeteksian 3 Citra Wajah 
Tabel 6 : Pengujian Pendeteksian 3 Citra Wajah

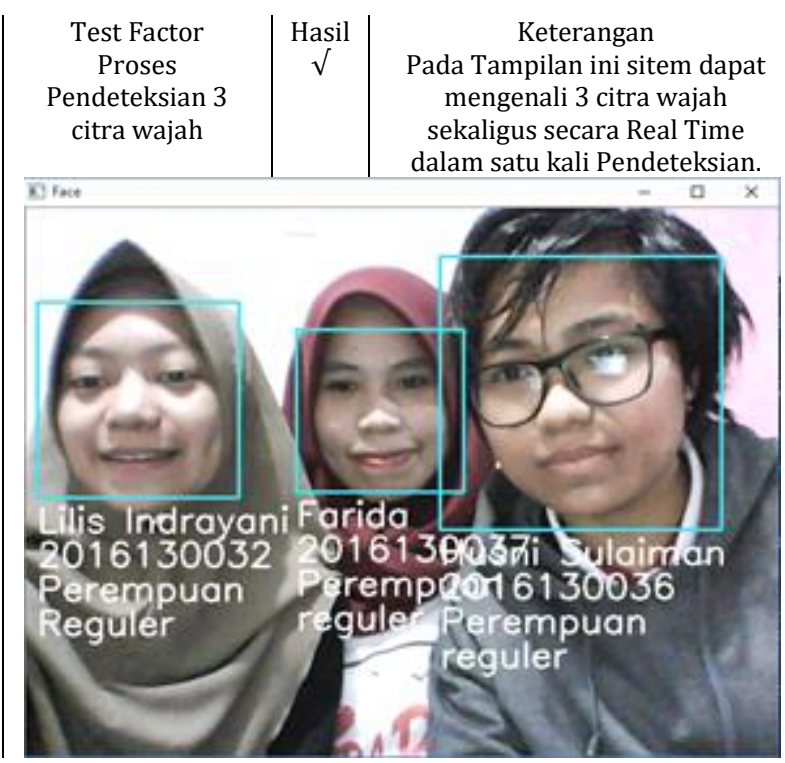

Pendeteksian Ketika Proses Pembelajaran

Tabel 7 : Pengujian Pendeteksian ketika Proses

\begin{tabular}{lll}
\hline \multicolumn{2}{c}{ Pembelajaran } \\
\hline Test Factor & Hasil Keterangan \\
\hline Proses & $\sqrt{ }$ & Pada Tampilan ini \\
Pendeteksia & sitem dapat \\
n ketika & mengenali banyak \\
Proses & citra wajah sekaligus \\
Pembelajara & secara Real Time \\
$\mathrm{n}$ & dalam satu kali \\
& Pendeteksian.
\end{tabular}

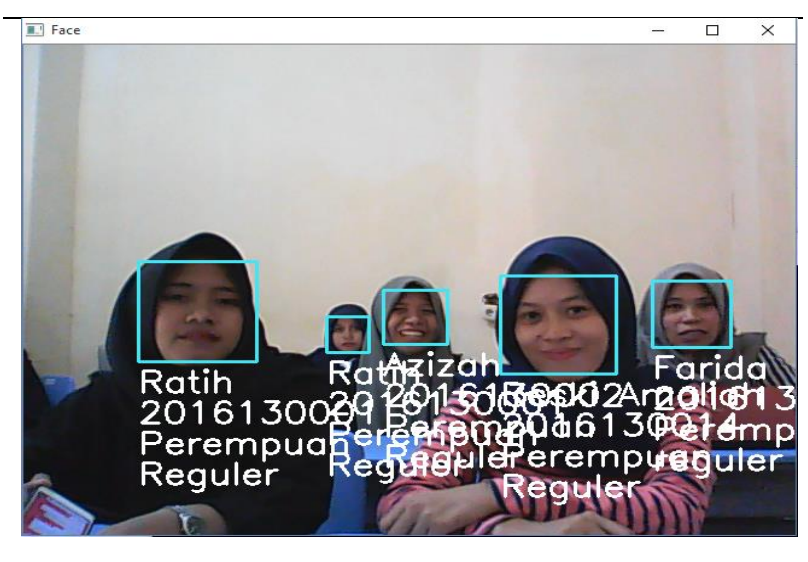

Pengujian Laporan Hasil Absensi Mahasiswa

Tabel 8 : Pengujian Laporan Hasil Absensi Mahasiswa

\begin{tabular}{lccc}
\hline \multicolumn{2}{c}{ Test Factor } & Hasil & Keterangan \\
\hline $\begin{array}{l}\text { Laporan } \\
\text { absesnsi }\end{array}$ & hasil & & $\begin{array}{l}\text { Pada Tampilan ini sitem dapat } \\
\text { menampilan laporan hasil absensi }\end{array}$ \\
\hline
\end{tabular}

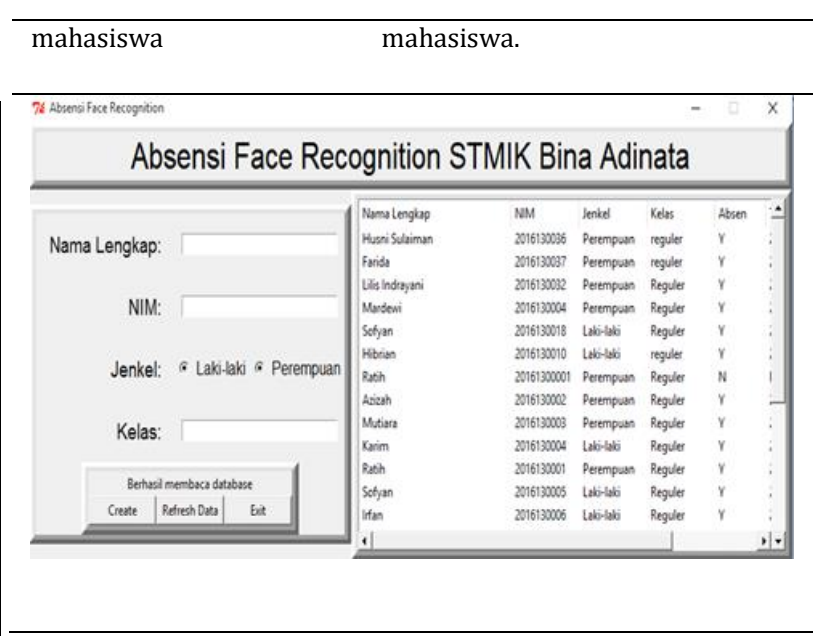

\section{Tingkat Persentase Absensi Pengenalan Wajah}

Untuk tingkat persentase hasil absensi pada pengenalan wajah ini dilakukan dengan uji coba terhadap 10 wajah, dimana tiap wajah tersebut memiliki 100 data set. Untuk lebih jelasnya perhatikan tabel pengujian di bawah ini.

\section{Pengujian Citra wajah berdasarkan dari segi} Pencahayaan

Tabel 9 : Pengujian citra wajah berdasarkan dari segi Pencahayaan

\begin{tabular}{|c|c|c|}
\hline $\begin{array}{c}\text { Citra Wajah yang } \\
\text { diuji }\end{array}$ & Pencahayaan & $\begin{array}{c}\text { Citra Wajah } \\
\text { Pencarian }\end{array}$ \\
\hline & Terang & Terdeteksi \\
\hline & Normal & Terdeteksi \\
\hline & Redup & Terdeteksi \\
\hline & Terang & Terdeteksi \\
\hline & Normal & Terdetekasi \\
\hline & Redup & Terdeteksi \\
\hline & Terang & Terdeteksi \\
\hline & Normal & Terdeteksi \\
\hline & Redup & Terdeteksi \\
\hline & Terang & Terdeteksi \\
\hline & Normal & Terdeteksi \\
\hline & Redup & $\begin{array}{l}\text { Tidak } \\
\text { Terdeteksi }\end{array}$ \\
\hline & Terang & Terdeteksi \\
\hline & Normal & Terdeteksi \\
\hline & Redup & Terdeteksi \\
\hline
\end{tabular}




\begin{tabular}{lll}
\hline $\begin{array}{c}\text { Citra Wajah yang } \\
\text { diuji }\end{array}$ & Pencahayaan & \multicolumn{1}{c}{$\begin{array}{c}\text { Citra Wajah } \\
\text { Pencarian }\end{array}$} \\
\hline & Terang & Terdeteksi \\
\cline { 2 - 3 } & Normal & Terdeteksi \\
\hline & Redup & $\begin{array}{l}\text { Tidak } \\
\text { Terdeteksi }\end{array}$ \\
\hline & Terang & Terdeteksi \\
\hline & Redup & Terdeteksi \\
\hline & & Tidak \\
& & Terdeteksi \\
\hline & Terang & Terdeteksi \\
\hline & Rermal & Terdeteksi \\
\hline & & Terdeteksi \\
\hline & & \\
\hline
\end{tabular}

Berdasarkan hasil pengujian yang telah dilakukan, maka diperoleh tingkat keberhasilan akurasi citra wajah berdasarkan dari segi Pencahayaan Terang, Normal, dan redup adalah sebagai berikut :

$$
\begin{array}{ll}
\text { Terang } & : \frac{10}{10} \times 100 \%=100 \% \\
\text { Normal } & : \frac{10}{10} \times 100 \%=100 \% \\
\text { Redup } & : \frac{7}{10} \times 100 \%=70 \%
\end{array}
$$

Total Akurasi keseluruhan dari Segi Pencahayaan adalah $\frac{27}{30} \times 100 \%=90 \%$

\section{Pengujian Citra Wajah berdasarkan dari segi Posisi Wajah}

Tabel 10 : Pengujian citra ajah berdasarkan dari segi Posisi Wajah

\begin{tabular}{ccc}
\hline $\begin{array}{c}\text { Citra Wajah yang } \\
\text { diuji }\end{array}$ & Posisi & $\begin{array}{c}\text { Citra Wajah } \\
\text { Pencarian }\end{array}$ \\
\hline & Depan & Terdeteksi \\
\hline & & \\
\hline
\end{tabular}

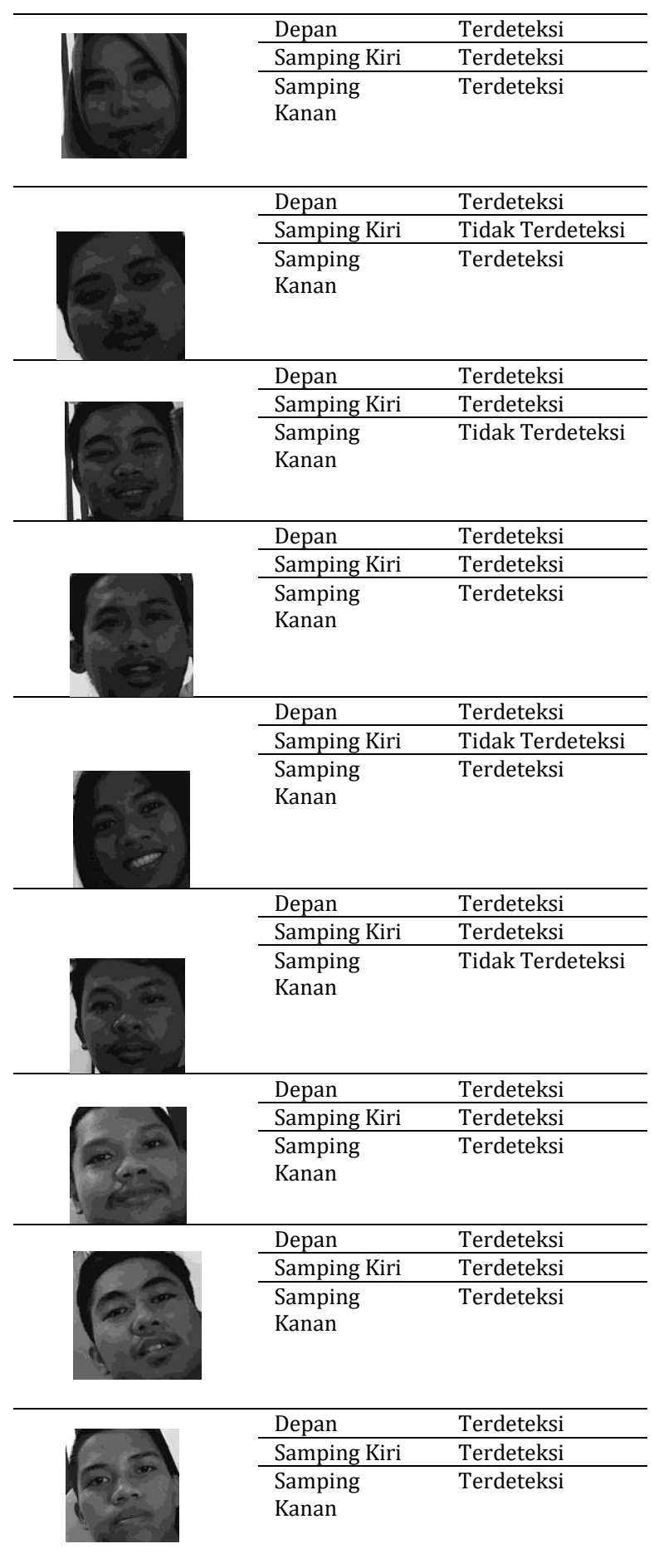

Berdasarkan hasil pengujian yang telah dilakukan, maka diperoleh tingkat keberhasilan akurasi citra wajah berdasarkan dari segi Posisi Wajah Depan, Samping Kiri, dan Samping Kanan adalah sebagai berikut :

$$
\begin{array}{ll}
\text { Depan } & : \frac{10}{10} \times 100 \%=100 \% \\
\text { Samping Kiri } & : \frac{8}{10} \times 100 \%=80 \% \\
\text { Samping Kanan } & : \frac{8}{10} \times 100 \%=80 \%
\end{array}
$$


Total Akurasi keseluruhan dari segi Posisi Wajah adalah $\frac{26}{30} \times 100 \%=86,6 \%$

\section{Pengujian Citra Wajah berdasarkan banyaknya wajah yang Terdeteksi}

Tabel 11 : Pengujian citra Wajah berdasarkan banyaknya wajah yang Terdeteksi
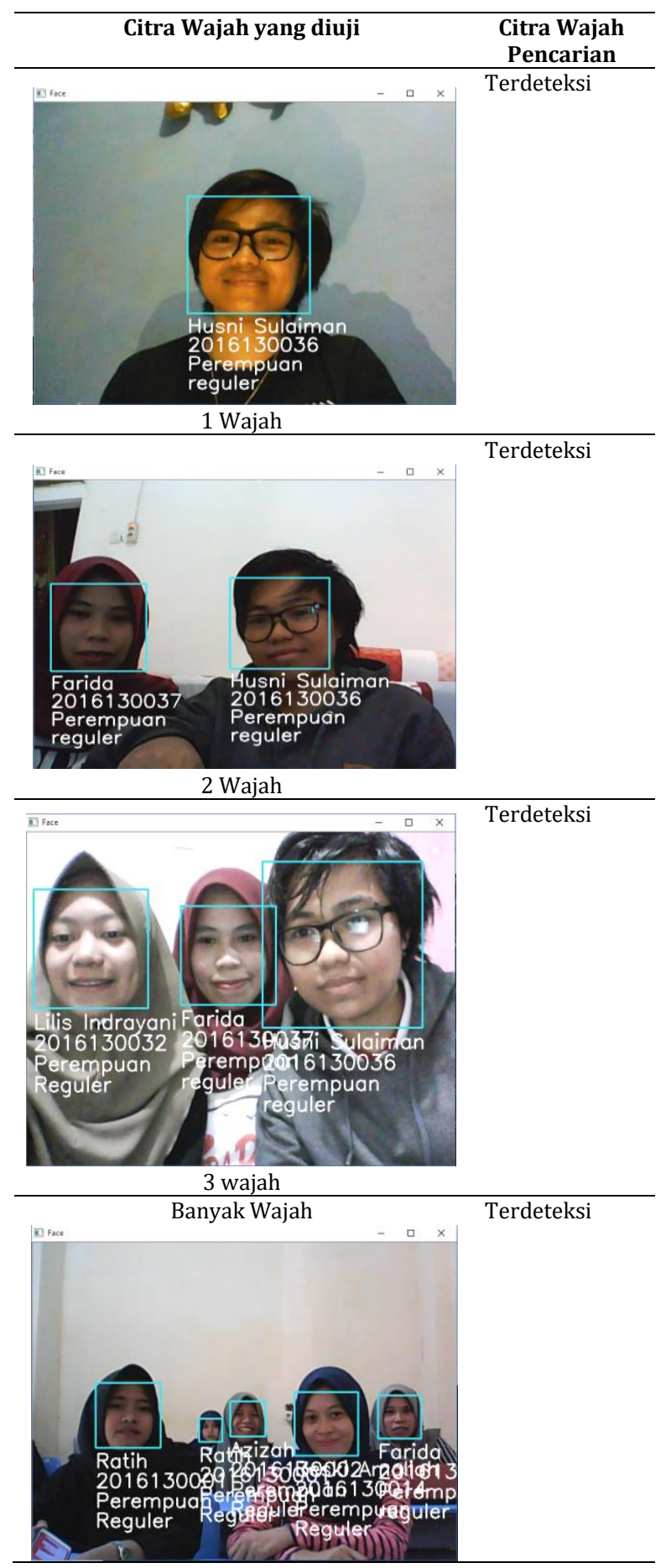

Aplikasi ini dapat Mengenali bukan Cuma 1 wajah, tetapi dia bisa mengenali banyak wajah selama wajah tersebut masih bisa terjangkau oleh Kamera yang digunakan.

\section{SIMPULAN DAN SARAN}

\section{Simpulan}

Berdasarkan dari uji coba sistem yang telah dibuat maka dapat di simpulkan sebagai berikut: Sistem absensi yang telah dibuat mampu melakukan proses absensi Secara realtime dengan mendeteksi wajah melalui metode pengenalan wajah yaitu Eigenface PCA (Priciple Component Analysis) dengan tingkat Total Akurasi keseluruhan dari Segi Pencahayaan adalah $90 \%$ dan Total Akurasi keseluruhan dari segi Posisi Wajah adalah 86,6 \%. Sistem ini dapat mengenali citra wajah baik dalam posisi lurus maupun menyamping. Sistem dapat mendeteksi bukan Cuma 1 wajah saja, tetapi sistem dapat mendeteksi semua wajah yang tertangkap kamera. Tingkat Keberhasilan Akurasi sangat dipengaruhi oleh Pencahayaan, semakin terang Pencahayaan maka tingkat keberhasilan akurasi juga semakin tingggi. Dan proses pendeteksian citra wajah juga berpengaruh terhadap jarak citra dengan kamera yang digunakan.

\section{Saran}

Pencahayaan dan jarak saat pengambilan citra wajah dan pengenalan wajah merupakan faktor yang sangat penting yang akan memepengaruhi keberhasilan akurasi pendeteksian citra. Oleh karena itu ketika ingin menggunakan Sistem ini dibutuhkan pencahayaan yang baik agar dapat mencapai akurasi yang lebih tinggi, dan juga untuk hasil maksimal sebaiknya menggunakan kamera dengan Spesifikasi yang tinggi atau menggunakan kamera CCTV.

\section{DAFTAR REFERENSI}

Chang, H., \& Robles, U. (2000). EE368 Final Project Report - Spring 2000: Face Detection. Stanford.

Hertyana, H. (2016). Pengaruh Sistem Absensi Fingerprint Terhadap Kinerja Karyawan Pada PT. Deltacomsel Indonesia. Jurnal Teknik Komputer, 2(2), 42-48. https://doi.org/10.31294/jtk.v2i2.1614

Purnia, D. S., \& Sumitro, A. (2015). PERANCANGAN PROGRAM ABSENSI SISWA REALTIME MENGGUNAKAN SMS GATEWAY PADA SMA NEGERI 69 JAKARTA. Seminar Nasional Ilmu 
Pengetahuan Dan Teknologi Komputer, 71INF.76.

Suhery, C., \& Ruslianto, I. (2017). Identifikasi Wajah Manusia untuk Sistem Monitoring Kehadiran Perkuliahan menggunakan Ekstraksi Fitur Principal Component Analysis (PCA). Jurnal Edukasi Dan Penelitian Informatika (JEPIN), 3(1), 9. https://doi.org/10.26418/jp.v3i1.19792

Yang, M.-H., Kriegman, D. J., \& Ahuja, N. (2002). Detecting Faces in Images: A Survey. IEEE
Transactions on Pattern Analysis and Machine Intelligence, 24(1), 34-58. https://doi.org/10.1109/34.982883

Yusuf, M., Ginardi, R. V. H., \& Ahmadiyah, A. S. (2016).

Rancang Bangun Aplikasi Absensi Perkuliaha n Mahasiswa dengan Pengenalan Wajah. Jurnal Teknik ITS, 5(2), A766-A770. https://doi.org/10.12962/j23373539.v5i2.1 7518 